\title{
Biodeterioration of Coastal Concrete Structures by Macro algae - Chaetomorpha antennina
}

\author{
Sriharibabu Jayakumar, Raman Saravanane ${ }^{\mathrm{b} *}$ \\ ${ }^{a}$ Assistant Professor, Sri Manakula Vinayagar Engineering College, \\ Madagadipet,Pondicherry, 605 107, India \\ ${ }^{\mathrm{b}}$ Assistant Professor, Environmental Engineering Laboratory, Department of Civil Engineering, \\ Pondicherry Engineering College, Pondicherry - 605 014, India
}

Received: June 26, 2009; Revised: October 8, 2009

\begin{abstract}
Puducherry is a coastal region in India where the growth of Chaetomorpha antennina is very abundant on all marine concrete structures. Though the detrimental effect of this Macro algae Chaetomorpha antennina is secondary, its effect has to be ascertained. To know its effect, M20 grade concrete cubes were cast and kept in the coastal area where there is abundant growth of Chaetomorpha antennina and also laboratory simulation has been carried out. The basic mechanism by which Chaetomorpha antennina deteriorates concrete structures has been highlighted and also the detrimental effect on the algal grown concrete surface were ascertained using SEM, EDX and XRD. The result showed that there is sustainable effect by the marine algae on the concrete surface.
\end{abstract}

Keywords: Marine algae, marine concrete structures, Chaetomorpha antennina, deterioration

\section{Introduction}

About $71 \%$ of the world is surrounded by ocean. The most important herbivores in ocean are phytoplankton and benthic algae. The marine algae familiarly known as seaweeds are a diverse group of photoautotrophic organisms of various shapes (filamentous, ribbonlike, or platelike) that contain pigments such as chlorophyll, carotenoids, and xanthophylls. The growth of marine algae is abundant in coastal area since sandy beaches provide excellent attachment points in a constantly moving and dynamic environment of the sandy shore. The first type of plant life to attach itself to the coastal concrete structure is filamentous macroalage. The colonisation is likely to be, due to the constant abrasion of the lower regions by the action of the tide lifting the sand and small stones from around the base of the structure. A number of seaweeds can be found in this type of environment although there are usually a few dominant species like Chaetomorpha antennina. These green algae are classified in the Phylum Chlorophyta. Many species of green algae grow attached to rocky and concrete substrates on or near the ocean's surface. In general, because they are attached to a substrate, they are not tossed up on the beach by the waves. These macroalgae are able to obtain different elements for their metabolism e.g. calcium, aluminum, silicon, iron etc by biosolubilization of materials. Such biosolubilization involves the production of organic acids by the metabolic activity of macroalgae. This acid deterioration is one of the best known biogeochemical mechanism of concrete decay ${ }^{16,17,18}$.

Puducherry is an Indian coastal region on the Bay of Bengal. There are many marine structures located in the coastal area. These structures deteriorate due to the macro flora Figure 1, 2 and 3 present in the sea water ${ }^{3,4,5,6,7}$. Though a secondary deterioration process, there is significant detrimental effect due to this macro flora ${ }^{9,14,15}$. The ambient condition prevailing in the coastal area helps the growth of Chaetomorpha antennina round the year. The growth of Chaetomorpha antennina on concrete structure in Puducherry region is found almost on all the structures. This study aims to ascertain the effect of marine chlorophyceae Chaetomorpha antennina on concrete structure. For this, concrete cubes were immersed in the coastal area where there is abundant growth of Chaetomorpha antennina and also simulated in the laboratory. Apart from this phycochemical analysis of Chaetomorpha antennina was carried on to find the chemical constituents occurring in the algae due to secondary metabolites. The surface of the concrete cube was chipped where there is a growth of Chaetomorpha antennina. Their morphological characteristics were observed using Scanning Electron Microscope (SEM) and surface analysis was done using Energy Dispersive X-ray analysis (EDAX). Mineralogical analysis is done using X-ray Diffraction (XRD).

\section{Materials and Methods}

\subsection{Concrete cubes}

To ascertain the effect of Chaetomorpha antennina on concrete, concrete cubes of M20 grade (Recommended in Indian Standard (IS 456-2000), M20 grade concrete mix was used for normal condition with w/c ratio 0.5 ) were prepared using OPC 53 Grade cement. OPC53 Grade was used since it is a high quality cement prepared from the finest raw material owing to optimum water demand, it contributes to a very low co-efficient of permeability of the concrete prepared. This improves the density of the concrete matrix and increases the durability of the concrete.

\subsection{Methods}

The procedures followed to determine the effects of Chaetomorpha antennina on concrete cubes were:

a) To culture Chaetomorpha antennina naturally, several concrete cubes were kept in the coastal area where there was abundant growth of Chaetomorpha antennina (Figure 4);

b) Concrete cubes were allowed to cure in ordinary water; and

c) Laboratory simulation was carried out to culture the Macro algae on the concrete cube. For the simulation, Humidity oven was used (Figures 5 and 6). The details of the oven are as follows: 

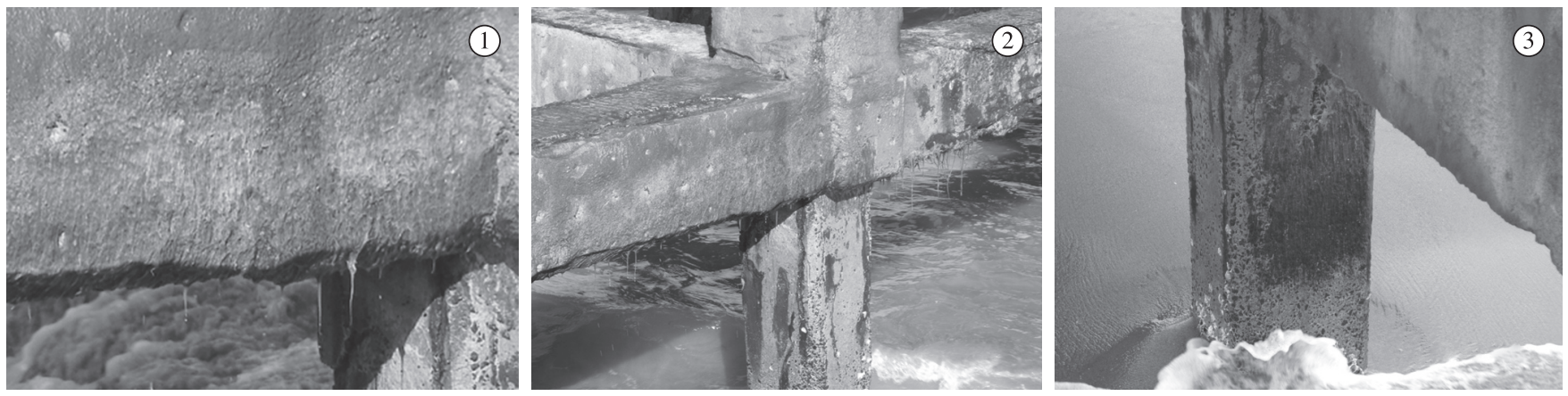

Figure 1,2 and 3. Growth of marine seaweed on structural components.

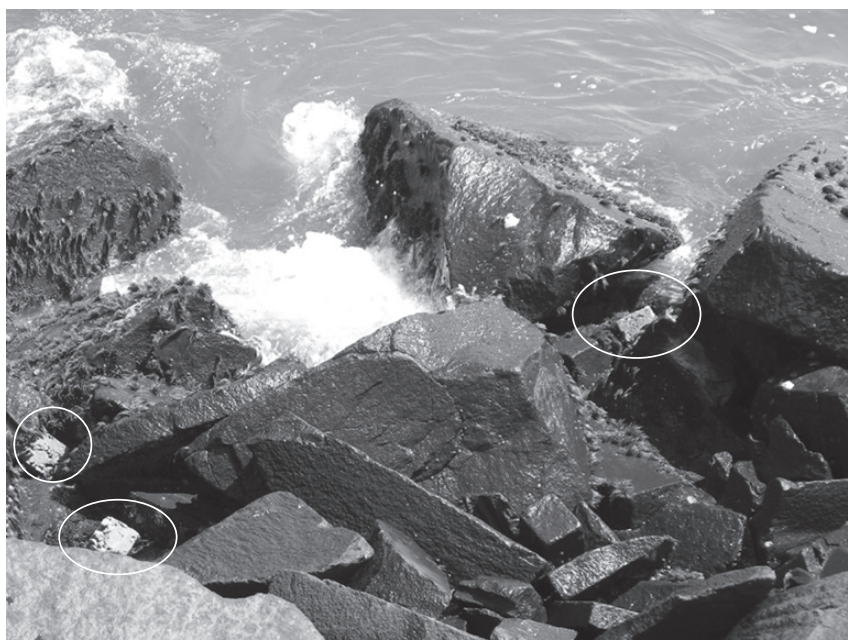

Figure 4. shows the natural culture of the marine algae Chaetomorpha antennina on concrete cube.
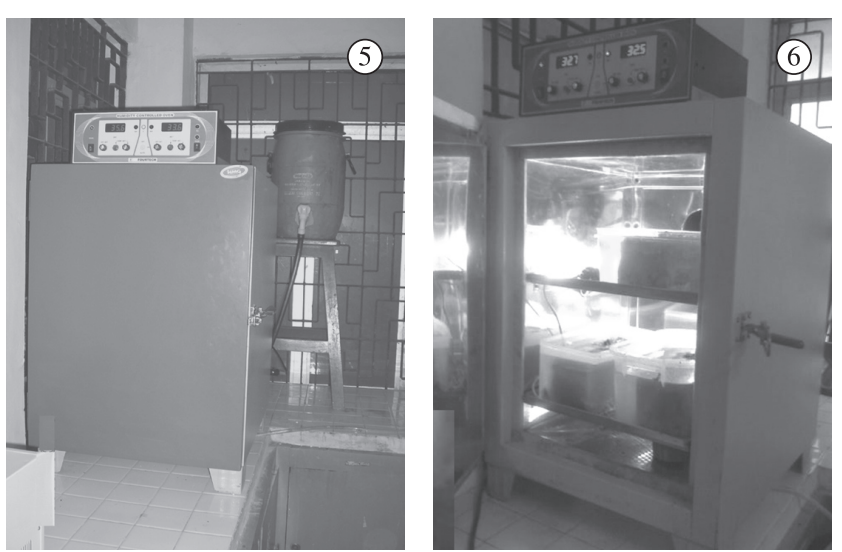

Figure 5 and 6. shows the Laboratory culture of the marine algae Chaetomorpha antennina on concrete cube.

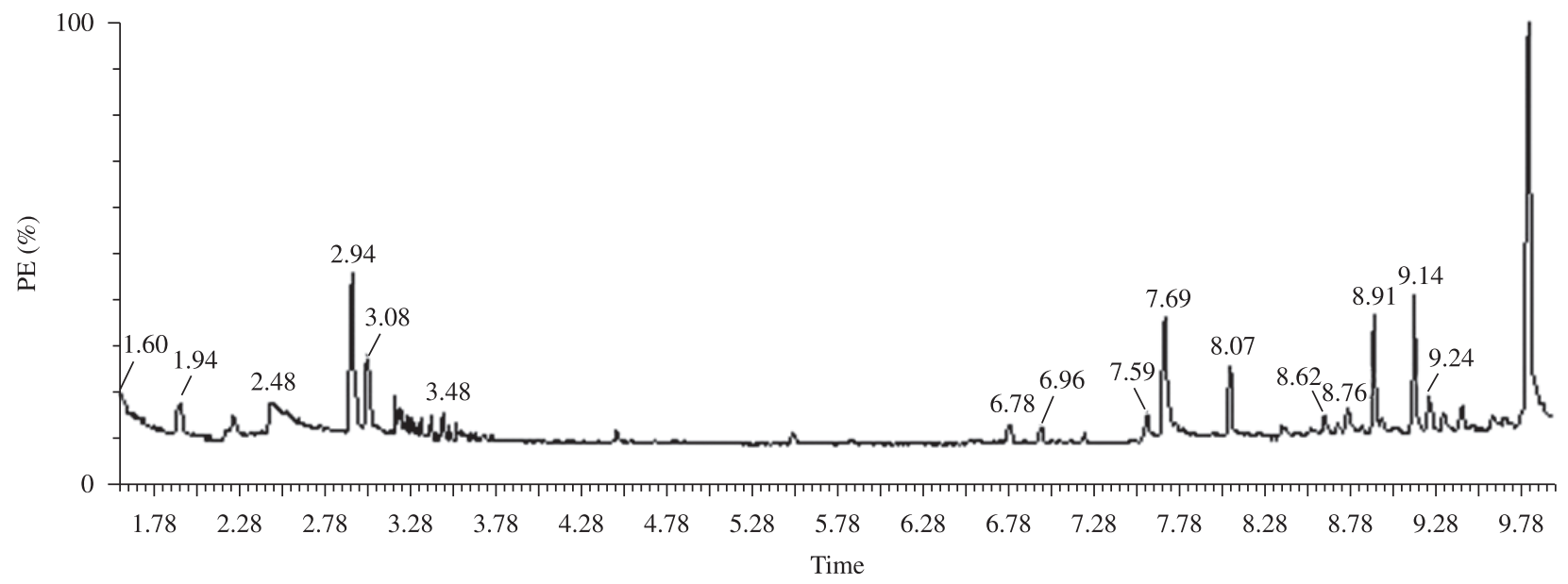

Figure 7. GC-MS of fatty acid fractions subjected to methylation obtained from Chaetomorpha antennina.

\subsubsection{Construction}

Double walled, inner Stainless Steel.304 / 316 grade and outer Stainless Steel or GI dully Epoxy Powder coat / finish, gap filled with Glass wool with outer metallic door provided. Chamber is illuminated with bulb.

\subsubsection{Cooling facility}

By Hermetically sealed branded compressor coupled with air cooled condensing unit fitted with Motor, fan blade, Electrical Accessories etc. Mounted on bottom of unit on heavy base frame. 
Table 1. Types of fatty acids present in Chaetomorpha antennina.

\begin{tabular}{|c|c|c|c|}
\hline Acid type & Systematic name & Common name & Molecular formula \\
\hline \multicolumn{4}{|c|}{ Saturated fatty acids } \\
\hline C14:0 & n-Tetradecanoate & Myristate & $\mathrm{C}_{15} \mathrm{H}_{30} \mathrm{O}_{2}$ \\
\hline $\mathrm{C} 17: 0$ & n-Hexadecanoate & Palmitate & $\mathrm{C}_{17} \mathrm{H}_{34} \mathrm{O}_{2}$ \\
\hline C19:0 & n-Nonadecanoate & Nonadecylate & $\mathrm{C}_{20} \mathrm{H}_{40} \mathrm{O}_{2}$ \\
\hline \multicolumn{4}{|c|}{ Monoenoic fatty acids } \\
\hline $\mathrm{C} 13: 1$ & Tridecenoate & Decylacrylate & $\mathrm{C}_{14} \mathrm{H}_{26} \mathrm{O}_{2}$ \\
\hline C19:1 & Nonadecenoate & Nonadecylenate & $\mathrm{C}_{20} \mathrm{H}_{38} \mathrm{O}_{2}$ \\
\hline $\mathrm{C} 21: 1$ & Heneicosenoate & - & $\mathrm{C}_{21} \mathrm{H}_{42} \mathrm{O}_{2}$ \\
\hline $\mathrm{C} 29: 1$ & Nonacocenoate & - & $\mathrm{C}_{30} \mathrm{H}_{58} \mathrm{O}_{2}$ \\
\hline \multicolumn{4}{|c|}{ Dienoic fatty acid } \\
\hline $\mathrm{C} 17: 2$ & 9,12,15 Heptaedcaienoate & - & $\mathrm{C}_{18} \mathrm{H}_{32} \mathrm{O}_{2}$ \\
\hline $\mathrm{C} 18: 2$ & Octadecadienoate & Linoleate & $\mathrm{C}_{19} \mathrm{H}_{34} \mathrm{O}_{2}$ \\
\hline
\end{tabular}

\subsubsection{Humidity creation}

Humidity Created with Steam and injected into working chamber.

\subsubsection{Heating facility}

Provided by long lasting Stainless Steel Tubular Heater with fins

\subsubsection{Temperature control}

Electronic Digital Temperature Controller-Cum Indicator with Dry Bulb and Wet Bulb principle.

The ambient condition maintained in the chamber is as follows. Samples were incubated under lighting conditions of $2000 \mathrm{~lx}$, 12 h/day with a "daylight" with white fluorescent lamp. The temperature was maintained at $30{ }^{\circ} \mathrm{C}$. The relative humidity was maintained as $90 \%{ }^{3}$.

To ascertain the detrimental effect of marine algae on concrete, 50 cubes were kept in coastal area where there is abundant growth of algae. Every three months, four cubes were tested to ascertain the effect of marine algae on the cubes. Totally 20 cubes has been tested for the past one and half years. The cubes tested after nine months only showed predominant changes in the surface analysis done using SEM and EDAX and mineralogical analysis using XRD. Moreover the concrete cubes showed a weight loss of around $0.4 \mathrm{~kg}$ after 9 months.

The laboratory simulated concrete cubes were started testing after six months and here also there is sustainable effect after eight months only and weight loss in this case is $\pm 0.6 \mathrm{~kg}$.

\subsection{Samples and microbiological procedures}

Concrete sample for analysis were taken from the concrete cube where Chaetomorpha antennina had attached itself from natural and artificial conditions. Before chipping the concrete surface for analysis, the biomass namely the marine chlorophyceae grown on the surface was scarped and placed in sterile plastic vessel and taken to the laboratory for identification. Apart from this concrete sample was chipped from the concrete cubes immersed in ordinary water in the laboratory.

\subsection{Morphological observations and surface analysis}

SEM was employed in studying the morphological characteristics of the structure. For this, samples were dehydrated by using an acetone series; critical point dried; and gold coated at $10^{-3} \mathrm{~mm} \mathrm{Hg}$ in sputter coat apparatus prior to SEM observations and EDAX analysis using a Hitachi S-3400N microscope.

\subsection{Mineralogical characterization}

The concrete samples were analyzed by powder X-ray Diffraction using Philips ${ }^{\circledR}$ PW1710 diffractometer with an automatic slit under the following conditions: emission radiation $=\mathrm{CuK} \alpha$, voltage $=40 \mathrm{kV}$, intensity $=30 \mathrm{nA}$, gonimeter speed $=0,120 / \mathrm{s}$. Gonimeter calibration was performed using silica standard. Data was interpreted using $X$ 'Pert High Score. Samples were ground in agar mortar and sieved to obtain a fraction of particle size less than $53 \mu \mathrm{m}$.

\subsection{Phycochemical investigation of marine}

\section{- Algae Chaetomorpha antennina}

Marine algae Chaetomorpha antennina was collected from the coastal area of Puducherry. It was washed thoroughly to remove epiphytes, animal casting, attached detritus and sand particles. Then it was rinsed with distilled water and shadow dried with aeration to avoid the breakdown of secondary metabolites under sunlight and high temperature. The dried algal materials were chopped and milled. The following procedures were followed to isolate fatty acid from the dried algae;

- Extraction

The dried, chopped and milled algal material was then soaked in methanol $(\mathrm{MeOH})$ in a large glass jar and was kept in the solvent for one month at room temperature. The extract of the material thus obtained was then filtered to remove all solid algal particles. Next it was evaporated on a rotary evaporator under reduced pressure. This yielded a dark green, thick residue;

- Saponification

An aliquot of the extract obtained was saponified with $10 \%$ $\mathrm{KOH}$ in $50 \%$ methanol and refluxed at $100{ }^{\circ} \mathrm{C}$ for 6 hours. The mixture was then concentrated under reduced pressure and later $\mathrm{H}_{2} \mathrm{O}$ and diethyl ester $\left(\mathrm{Et}_{2} \mathrm{O}\right)$ were added. It was then shaken vigorously and the $\mathrm{Et}_{2} \mathrm{O}$ layer was separated. The $\mathrm{Et}_{2} \mathrm{O}$ layer was evaporated and used for fatty acid analysis;

- Esterification

All the fatty acid fractions obtained were subjected to methylation and 1.5 -2.0 mL ethereal diazomethane was added to the fatty acid mixture. The reaction mixture was left in the fuming chamber at room temperature, over night until dissolved. The aliquots were then directly injected to a Hewlett Packard ${ }^{\circledR}$ 
gas chromatograph - mass spectrophotometer (GC-MS) with 11/73 DEC computer system (Figure 7); and

- The methanolic extract of Chaetomorpha antennina revealed the presence of three saturated and six unsaturated fatty acids. The details are as show in Table 1.

\subsection{Experimental Method - Flow Chart}

Scheme 1 shows the schematic way of experimental method carried on to determine the effect of marine algae on concrete.

\section{Result and Discussion}

\subsection{Macro-algae results}

The species collected by scarping from the surface of concrete was identified as Chaetomorpha antennina (Figure 8).

\subsection{Biodeterioration mechanisms}

All surfaces in natural environments either aerial or sub-aerial are colonized by microorganisms and sub-aerial structures are colonized severely. Concrete is one material that can be readily colonized by Macro algae ${ }^{10}$ as it is revealed in this work. Macro algae are able to obtain several elements they need for their metabolism (e.g. calcium, aluminium, silicon, iron and potassium) from the concrete ${ }^{1,2,8,12,13}$ by biosolubilization in the presence of sea water. This biosolubilization process generally involves the production of various organic acids (Table 1) by the marine algae. The release of aggressive acids is one of the best known biogeochemical destructive mechanisms ${ }^{16,17,18}$ on concrete surfaces. It occurs through the leaching of binding materials with the consequent weakening of the crystal structure ${ }^{11}$. The final result of this type of biodeterioration is the physical and mechanical breakdown of the concrete matrix ${ }^{16}$.

\subsection{Surface analysis by EDAX}

SEM Figures 9, 10, 11, and EDAX results depicted in the Table 2, 3 and 4 and EDAX Figures 12, 13, and 14 elucidate that the base material has been modified. In the case of concrete cubes cured in ordinary water (control concrete) the silica level is $10.37 \%$ atom while calcium level is $9.18 \%$ atom. The EDAX results of the algal affected concrete shows that the calcium level has tremendously increased to $46.06 \%$ atom while silica level had decreased to $1.29 \%$ atom ${ }^{7,15}$. While in the case of simulated condition, calcium level had tremendously increased to $44.01 \%$ atom while silica level had increased to $4.23 \%$ atom. This proves that the calcium level in the algal affected concrete surface in natural and laboratory condition has increased tremendously. This high level of calcium is due to dissolution of calcium in concrete by organic acid produced by marine chlorophyceae Chaetomorpha antennina and precipitation of the organic salt upon dehydration. This is an indication of the alteration of the base material.

\subsection{Mineralogical analysis by $X$-ray diffraction}

Figure 15 shows the mineralogical analysis of concrete by $\mathrm{XRD}$. The following are the crystals present in concrete specimen immersed in ordinary water Portlandite $\left(\mathrm{Ca}(\mathrm{OH})_{2}\right)$, Silica, Yeelimite

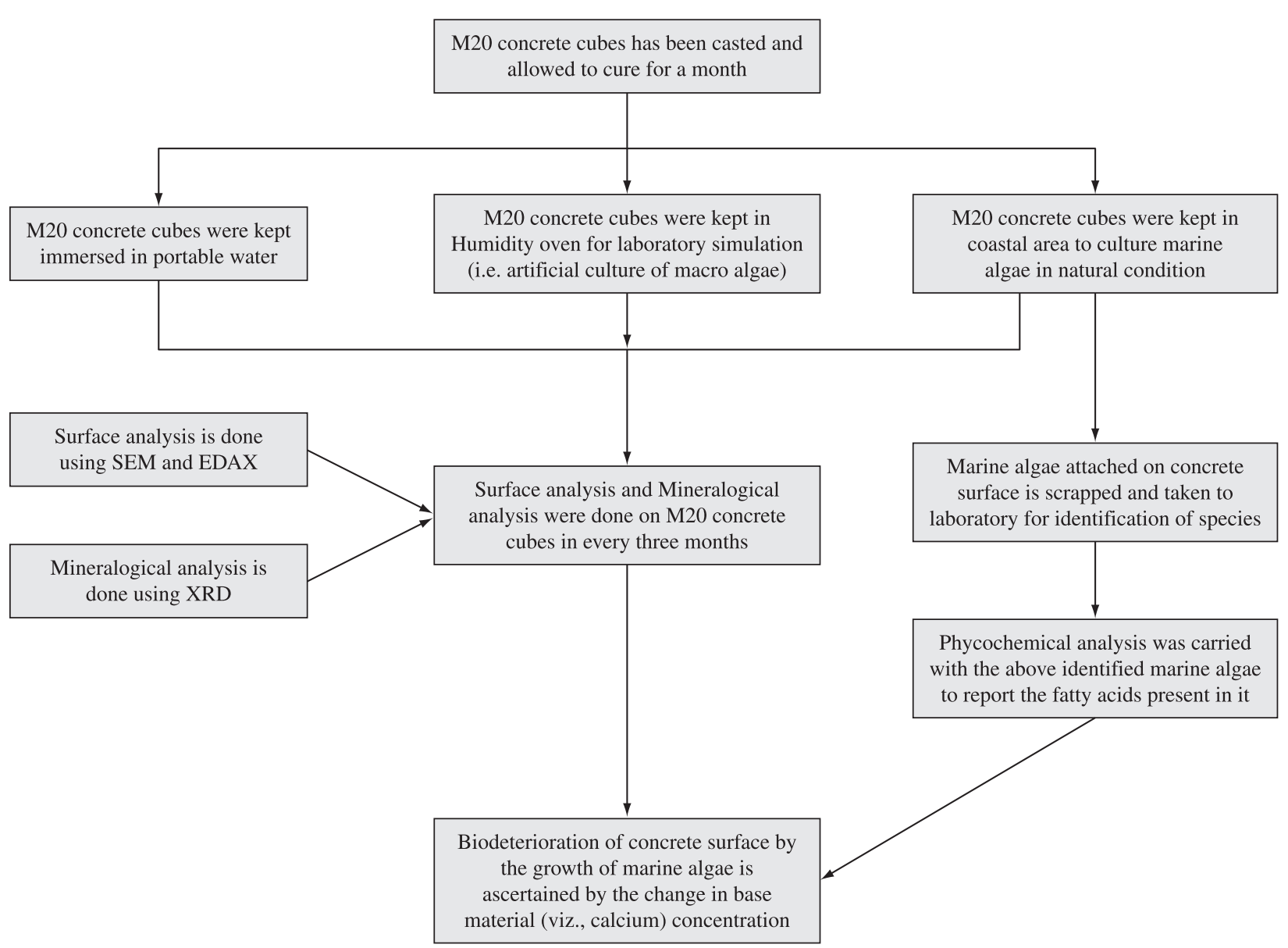

Scheme 1. Schematic way of Experimental Method. 


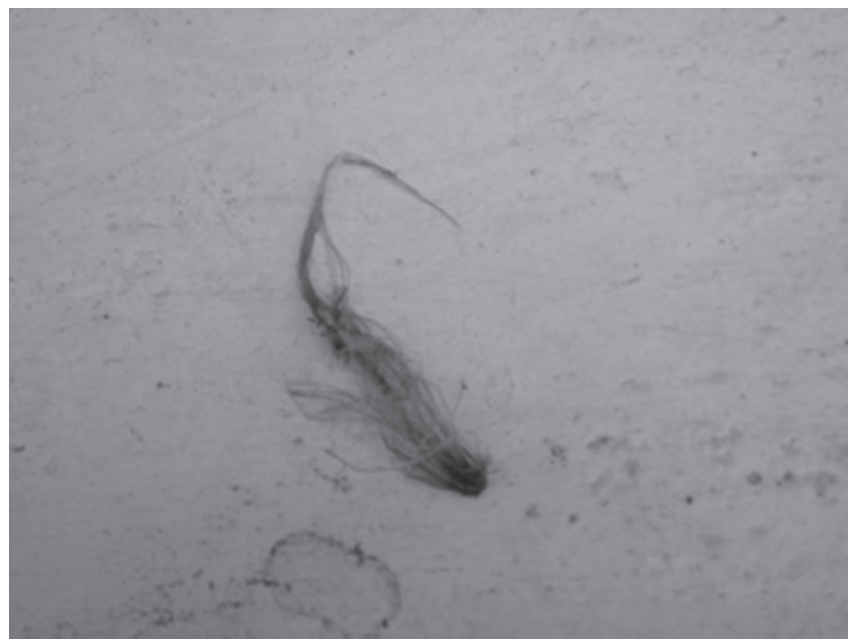

Figure 8. Chaetomorpha antennina species.

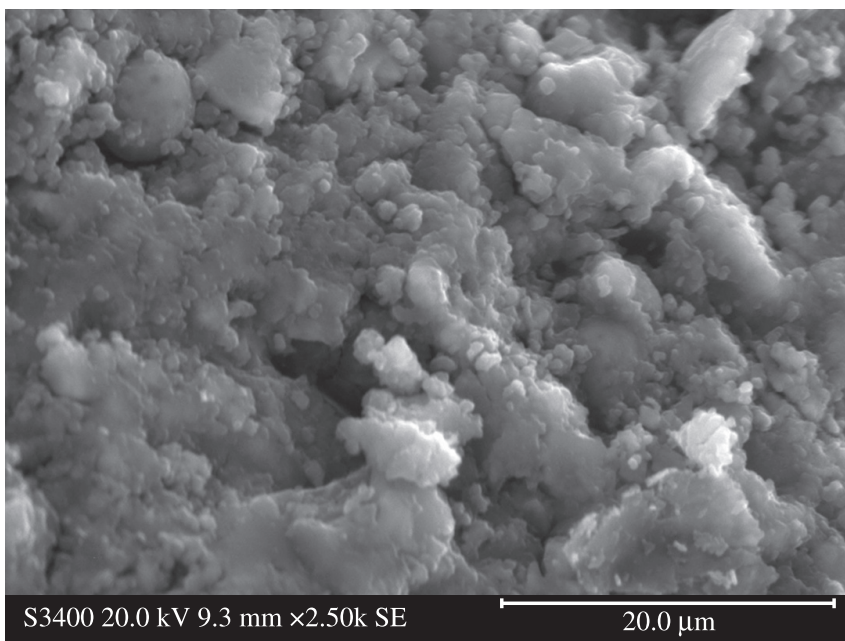

Figure 9. SEM of concrete specimen immersed in ordinary water (magnification: $\times 2500)$ - (control concrete)

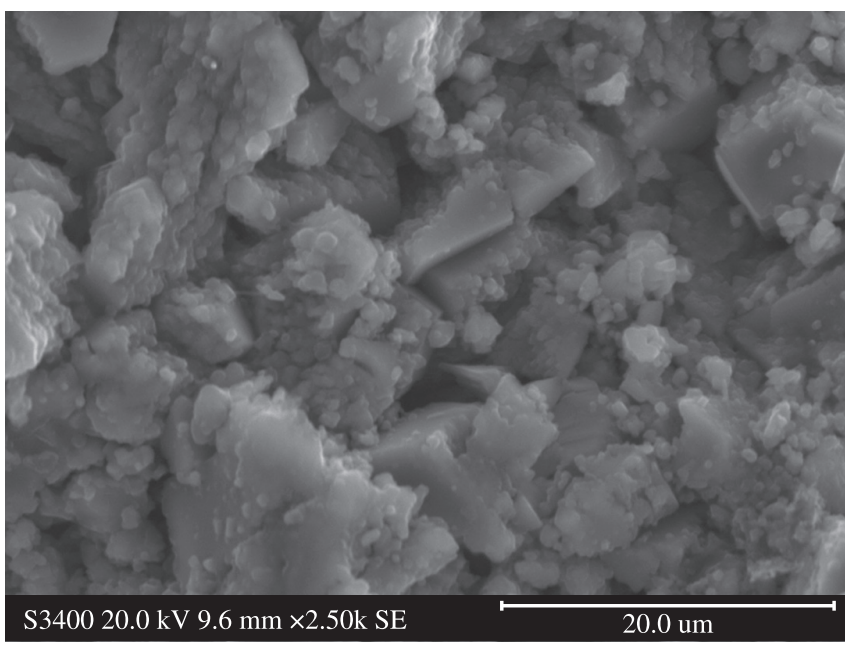

Figure 10. SEM of Chaetomorpha antennina attached concrete surface in natural condition (magnification: $\times 2500$ ).

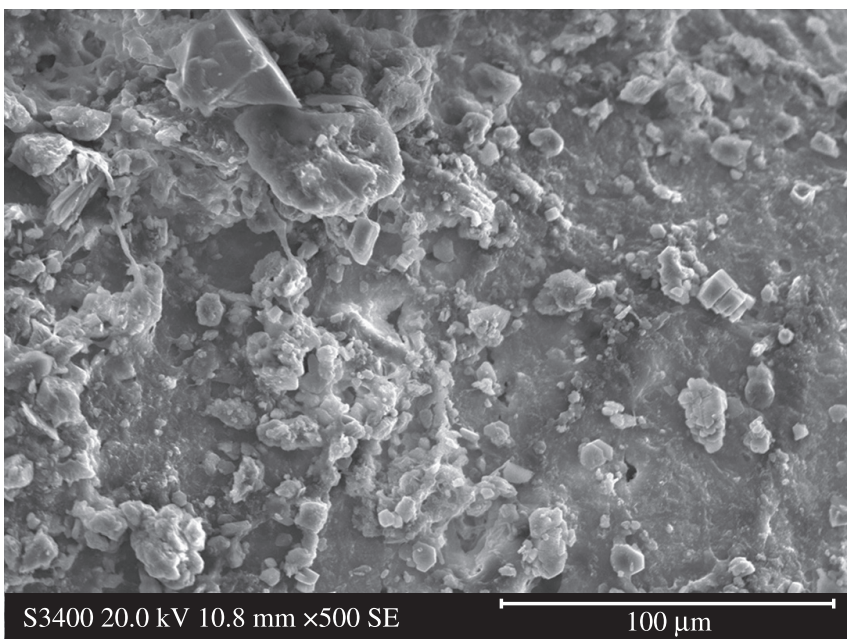

Figure 11. SEM of Chaetomorpha antennina attached concrete surface in laboratory condition (magnification: x5000).

Table 2. EDAX analysis of concrete specimen immersed in ordinary water(control concrete).

\begin{tabular}{cc}
\hline $\begin{array}{c}\text { Element } \\
\text { Line }\end{array}$ & Atom \% \\
\hline O K & 58.44 \\
Mg K & 11.76 \\
Al K & 6.38 \\
Si K & 10.37 \\
S K & 1.08 \\
S L & - \\
K K & 0.25 \\
K L & - \\
Ca K & 9.18 \\
Ca L & - \\
Fe K & \\
Fe L & 2.55 \\
Total & - \\
\hline
\end{tabular}

Table 3. EDAX analysis of Chaetomorpha antennina attached concrete surface in natural condition.

\begin{tabular}{cc}
\hline Element Line & Atom \% \\
\hline O K & 50.59 \\
Na K & 0.19 \\
Mg K & 0.27 \\
Al K & 0.72 \\
Si K & 1.29 \\
K K & 0.63 \\
K L & - \\
Ca K & 46.06 \\
Ca L & - \\
Ti K & 0.04 \\
Ti L & - \\
Fe K & 0.07 \\
Fe L & - \\
Total & 100.00 \\
\hline
\end{tabular}


Table 4. EDAX analysis of Chaetomorpha antennina attached concrete surface in natural condition.

\begin{tabular}{cc}
\hline Element Line & Atom $\%$ \\
\hline C K & 0.00 \\
O K & 45.14 \\
Na K & 3.86 \\
Mg K & 2.76 \\
Si K & 4.23 \\
Ca K & 44.01 \\
Ca L & - \\
Total & 100.00 \\
\hline
\end{tabular}

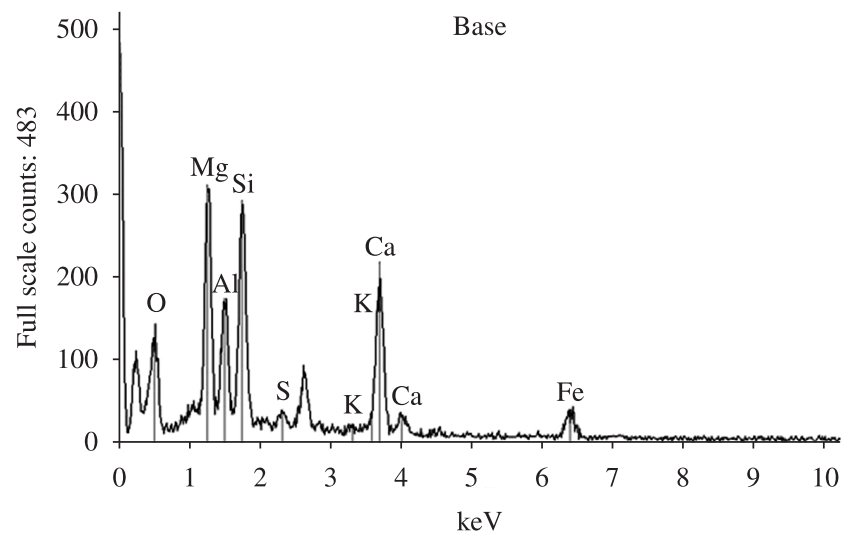

Figure 12. EDAX of concrete specimen immersed in ordinary water (control concrete).

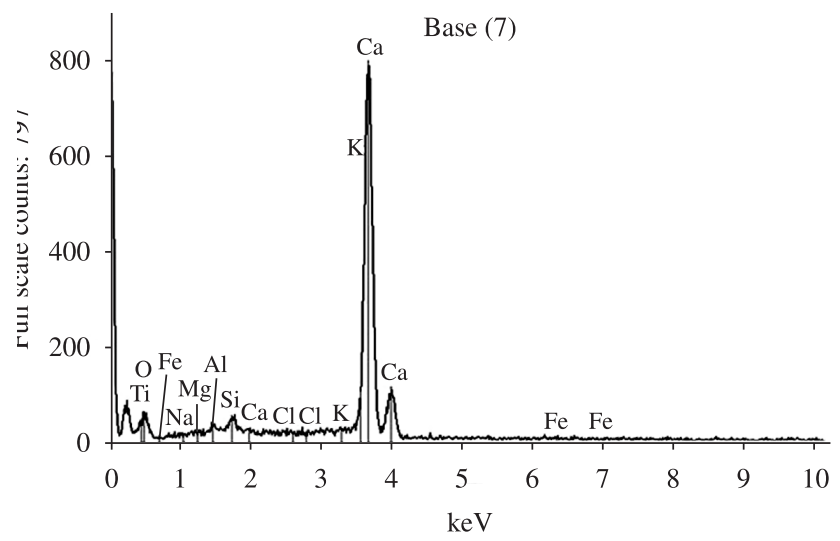

Figure 13. EDAX of Chaetomorpha antennina attached concrete surface in natural condition.

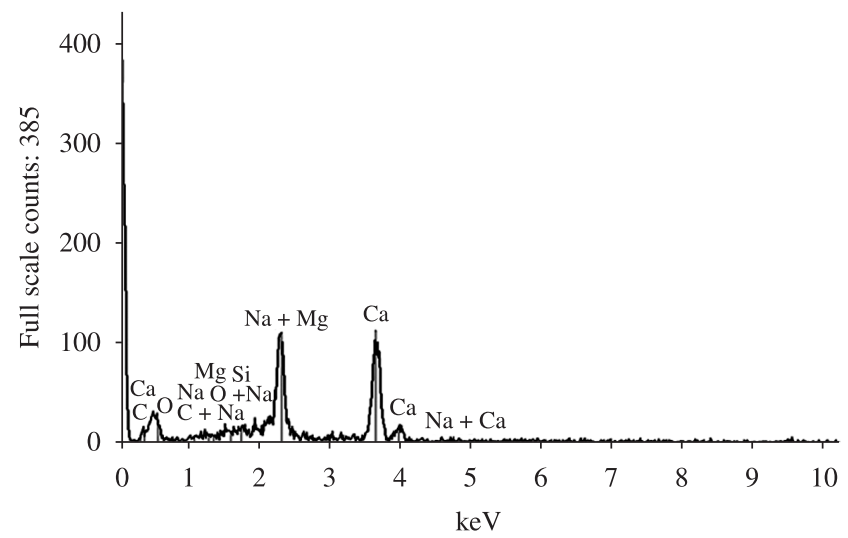

Figure 14. EDAX of Chaetomorpha antennina attached concrete surface in laboratory condition.

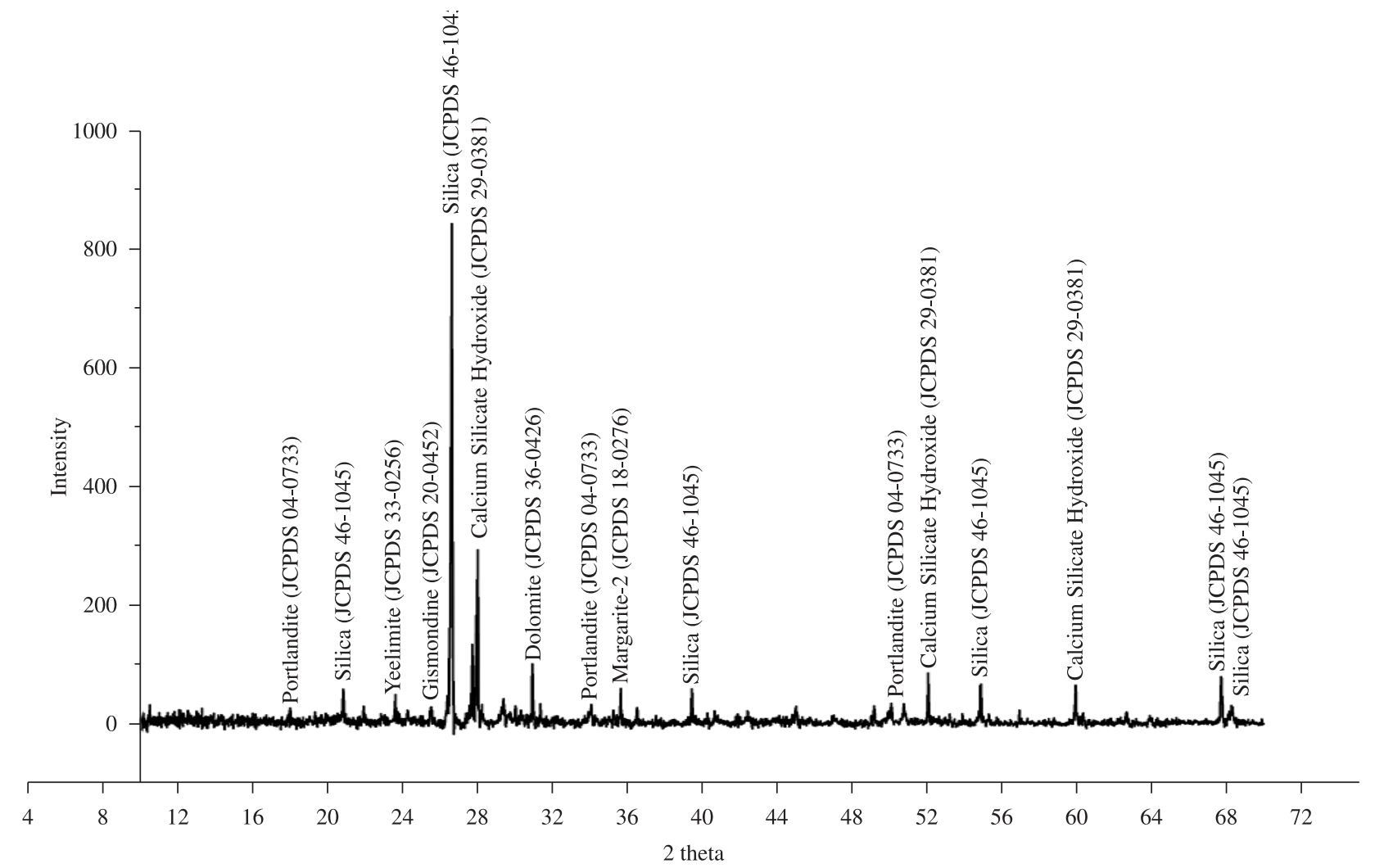

Figure 15. XRD of concrete specimen immersed in ordinary water (Control concrete). 


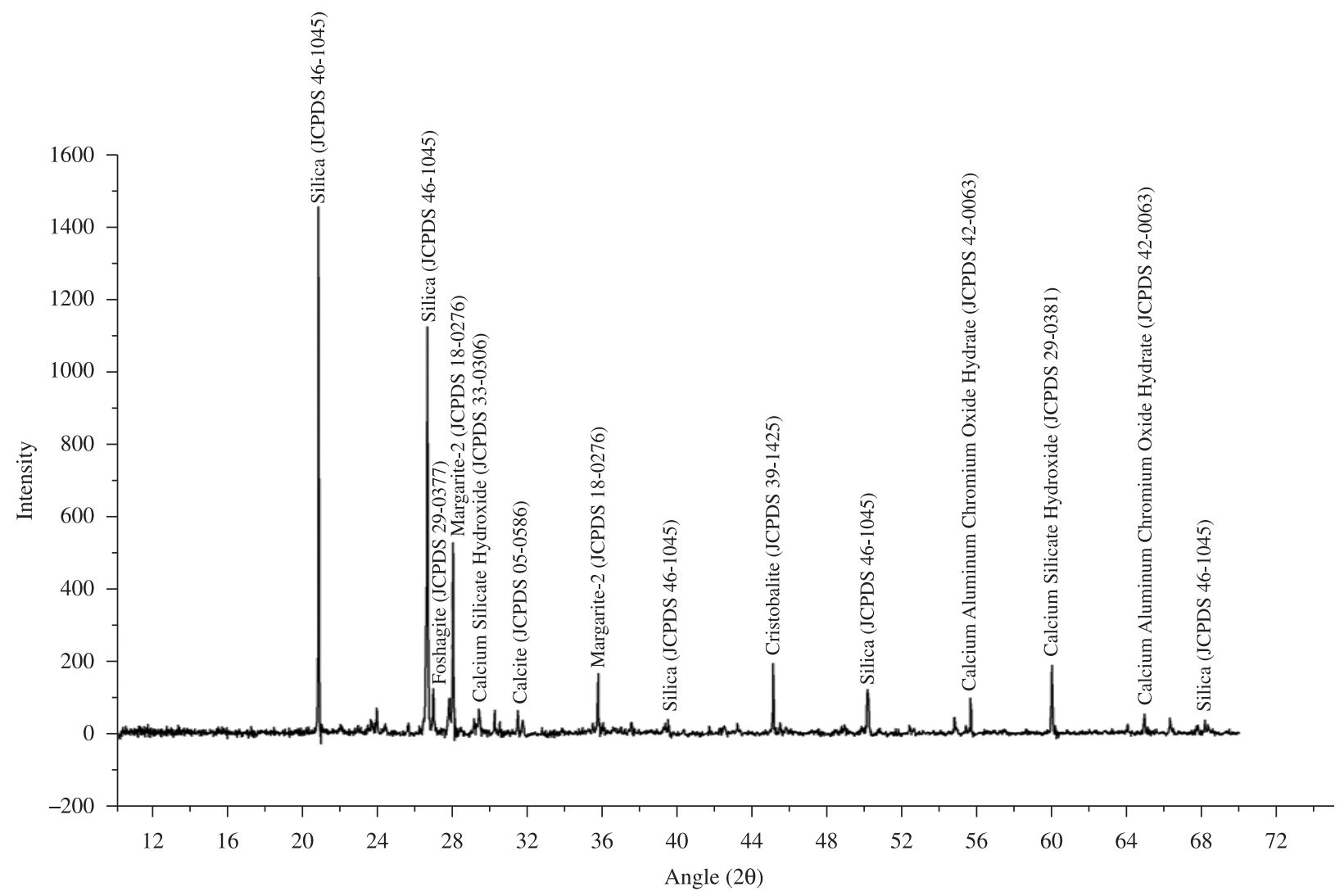

Figure 16. XRD of Chaetomorpha antennina attached concrete surface in natural condition.

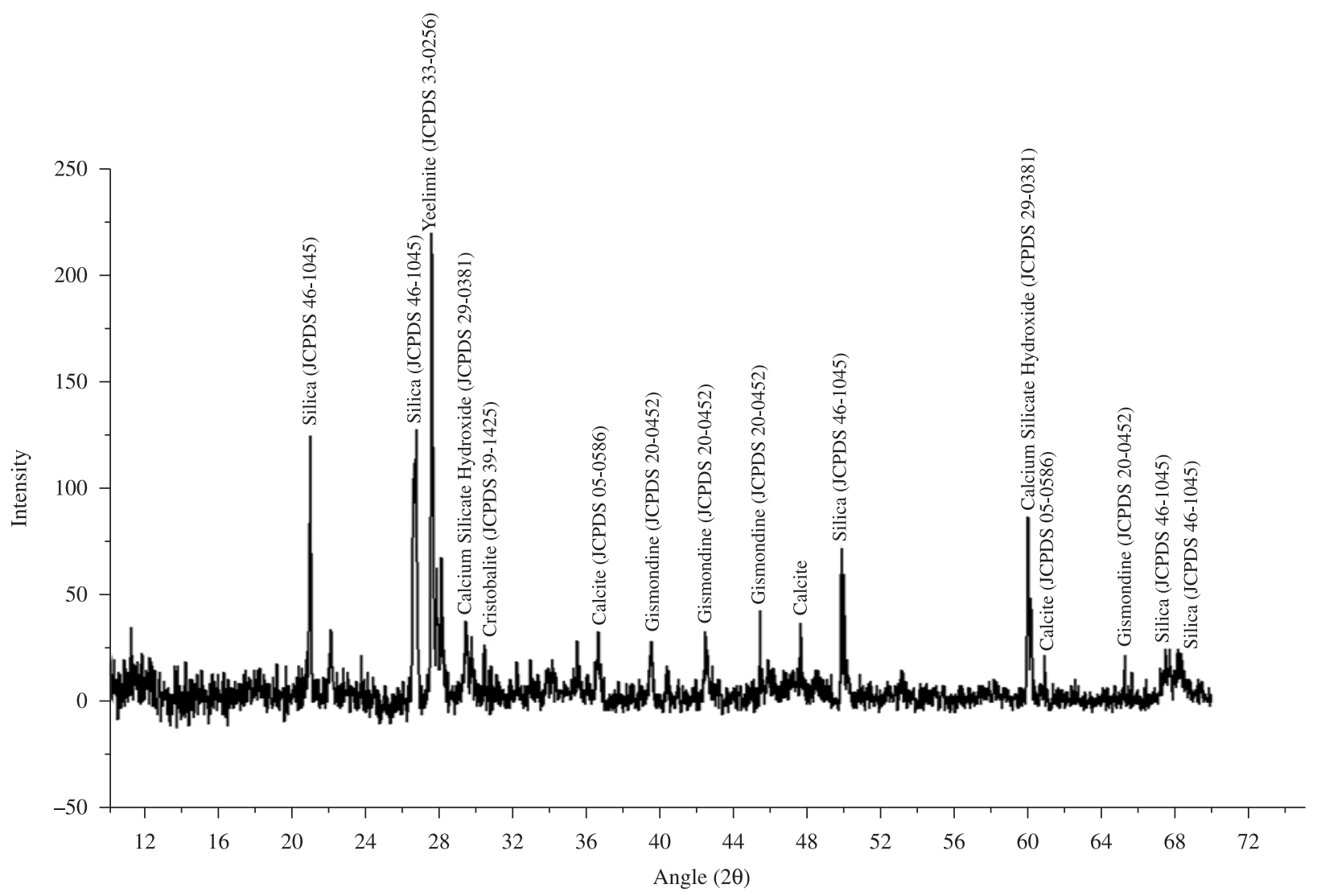

Figure 17. XRD of Chaetomorpha antennina attached concrete surface in laboratory condition. 
$\left(\mathrm{Ca}_{3} \mathrm{Al}_{6} \mathrm{O}_{12} \cdot \mathrm{CaSO}_{4}\right)$, Gismondine $\left(\mathrm{CaAl}_{2} \mathrm{Si}_{2} \mathrm{O}_{8} \cdot 4 \mathrm{H}_{2} \mathrm{O}\right)$, Dolomite $\left(\mathrm{CaMg}\left(\mathrm{CO}_{3}\right)_{2}\right)$, Maragarite-2 $\left(\mathrm{CaAl}_{2}\left(\mathrm{Si}_{2} \mathrm{Al}_{2}\right) \mathrm{O}_{10}(\mathrm{OH})_{2}\right)$, Calcium Silicate Hydroxide $\left(\mathrm{Ca}_{4} \mathrm{H}_{2} \mathrm{O}_{15.5} \mathrm{Si}_{5}\right)$. The intensity of Portlandite is 34 at $18^{\circ}, 34^{\circ}, 50^{\circ}$ while silica has a maximum intensity of 846 at $26^{\circ}$ and Calcium Silicate Hydroxide has a intensity of 294 at $28^{\circ}$.

Figure 16 shows XRD pattern for algal attached concrete in natural condition. Compounds like Foshagite $\left(\mathrm{Ca}_{4} \mathrm{H}_{2} \mathrm{O}_{11} \mathrm{Si}_{3}\right)$, Calcium Silicate Hydrate $\left(\mathrm{Ca}_{1.5} \mathrm{SiO}_{3.5} \cdot \mathrm{xH}_{2} \mathrm{O}\right)$, Calcite $\left(\mathrm{CaCO}_{3}\right)$, and Cristobalite $\left(\mathrm{SiO}_{2}\right)$, Calcium Aluminum Chromium Oxide Hydrate are present here which are absent in the concrete specimen immersed in ordinary water (Control Concrete). Apart from this, it is noticed that the Silica intensity (1452) is very high at $21^{\circ}$ compared to $26^{\circ}$ which is 1119 only. Similarly the intensity of Calcium Silicate Hydroxide at $60^{\circ}$ is $64^{\circ}$ in control concrete while it is 187 here. Compounds like Yeelimite, Gismondine and Portlandite are completely absent here. The absence of Portlandite (i.e. Calcium Hydroxide) shows that the alga has utilized it for its metabolic actiity ${ }^{1,2}$.

Figure 17 shows the XRD pattern for algae attached concrete in simulated condition. It is notified that the intensity of Yeelimite is very high (218) while there are two Silica peaks at $20^{\circ}$ and $26^{\circ}$ with more or less equal intensity of 126 . The intensity of Calcium Silicate Hydroxide at $60^{\circ}$ is $64^{\circ}$ in control concrete while it is 87 here. Apart from this new compounds like Cristobalite and Calcite are present here which is not notified in control concrete. Three peaks are noticeable for portlandite in control concrete which is totally absent in this case. Similarly Margarite- 2 is not noticeable here. This shows that algae have utilized the calcium hydroxide for its metabolic activity ${ }^{1,2}$.

\section{Conclusion}

Samples obtained from the concrete cubes immersed in ordinary potable water and the Macro algae, Chaetomorpha antennina attached concrete surfaces from natural as well as laboratory simulated conditions were studied and the detrimental effect of metabolic activity of Chaetomorpha antennina on concrete was identified. Surface analysis obtained from EDAX suggests that biodeterioration may be affected through biosolubilization mechanism involving the production of metabolic acids by algae. EDAX results elucidate that the calcium level is tremendously increased to $46.06 \%$ in natural condition and $44.01 \%$ in laboratory simulation, while the silica level is decreased remarkably. XRD reveals that crystals like Yeelimite, Gismondine and Portlandite which are present in control concrete are found to be completely absent in algal attached concrete. This showed that the marine algae have utilized them for their metabolic activity. Hence, it is concluded that the base material has been altered severely. Thus the presence of chlorophyceae would serve as a primary support for heterotrophic biofilm, supporting organic matter for growth through photosynthesis.

\section{References}

1. Bertron A, Escadeillas G and Duchesne J. Cement paste alteration by liquid manure organic acids: chemical and mineralogical characterization. Cement and Concrete Research. 2004; 34(10):1823-1835.
2. De-Belie N, Debruyckere M, Nieuwenburg D Van and De-Blaere B. Attack of concrete floors in pig houses by feed acids: influence of fly ash addition and cement-bound surface layers. Journal of Agricultural Engineering Research. 1997; 68(2):101-108.

3. Dubosc A, Escadeillas G and Blanc PJ. Characterization of biological stains on external concretewalls and influence of concrete on underlying material. Cement and Concrete Research. 2001; 31(11):1613-1617.

4. Gaylarde CC and Gaylarde PM. 1998. Phototrophic biomass on monuments of cultural heritage inLatin America. In: Proceedings of Latincorr; 1998; Houston: NACE International; 1998. (Paper S11-03)

5. Guiamet PS, Saravia SG and Videla HA. Biodeteriorating microorganisms of two archaeologicalbuildings at the site of Uxmal, Mexico. In: Proceedings of Latincorr; 1998; Houston: NACE International; 1998. (Paper S11-01).

6. Herrera LK, Arroyave C and Videla HA. Atmospheric and biological deterioration of two churches from the cultural heritage of the city of Medellin, Colombia. In: Saiz-Jimenez C. (Ed.). Molecular biology and cultural heritage. Lisse: Balkema Publishers; 2003. p. 271-276.

7. Herrera LK, Arroyave C, Guiamet P, Saravia SG and Videla H. Biodeterioration of peridotite and other constructional materials in a building of the Colombian cultural heritage. International Biodeterioration and Biodegradation. 2004; 54(2-3):135-141.

8. Keller WD. Principles of chemical weathering. Columbia: Lucas Brothers Publishers; 1957.

9. McCormack K, Morton LHG, Benson J, Osborne BN and McCabe RW. A preliminary assessment of concrete biodeterioration by microorganisms. In: Gaylarde CC. (Ed.). Microbially influenced corrosion of materials. Berlin: Springer; 1996. p. 168-186.

10. Silva MR and Pinheiro SMM. Microbial impact on concrete microstructure of world heritage in Brasilia. In: Proceedings of International RILEM Workshop on Performance Based; 2006; Madrid: RILEM.

11. Silva MS and Rosowsky DVPE. Biodeterioration of construction materials: state of the art and future challenges. Journal of Materials in Civil Engineering. 2008; 20(5):352-365.

12. Schalscha EB, Appelt $\mathrm{H}$ and Schatz A. Chelation as weathering mechanisms: I effect of complexing agents on the solubilization of iron from minerals and granodiorite. Geochimica et Cosmochimica Acta. 1967; 31(4):587-596.

13. Schatz A, Schatz V and Martin JJ. Chelation as a biochemical factor. Geology Society of the American Bulletin. 1957; 68:1792-1793.

14. Videla HA and Characklis WG. Biofouling and microbiologically influenced corrosion. International Biodeterioration and Biodegradation. 1992; 29(3-4):195-212.

15. Videla HÁ, Guiamet OS and Saravia SG. Biodeterioration of Mayan archaeological sites in the Yucatan Pennsula, Mexico. International Biodeterioration and Biodegradation. 2000; 46(4):335-341.

16. Warscheid T and Braams J. Biodeterioration of stone: a review. International Biodeterioration and Biodegradation. 2000; 46(4):343-368.

17. Warscheid $T$ and Krumbein WE. General aspects and selected cases. In: Heitz E, Flemming HC, Sand W. (Eds.). Microbially inuenced corrosion of materials. Berlin: Springer Verlag; 1996.

18. Sand W. Microbial mechanism of deterioration of inorganic substrates: a general mechanistic overview. International Biodeterioration and Biodegradation. 1997; 40(2-4):183-190. 